\title{
Benzophenone Derivatives Showed Dual Anti-Inflammatory and Antiproliferative Activities by Inhibiting COX Enzymes and Promote Cyclin E Downregulation
}

\author{
Laís R. S. Folquitto, ${ }^{\#, a}$ Thiago B. de Souza, ${ }^{\#, b}$ Jaqueline P. Januario, ${ }^{a}$ \\ Isadora M. Nascimento, ${ }^{a}$ Brenda T. V. Brandão, ${ }^{c}$ Maria E. C. Moreira, ${ }^{d}$ \\ Renato O. Horvath, ${ }^{e}$ Marcelo H. Santos, ${ }^{d}$ Luiz F. L. Coelho, ${ }^{e}$ Marcia P. Veloso, ${ }^{c}$ \\ Marisi G. Soares, ${ }^{a}$ Diogo T. Carvalho, ${ }^{\circledR c}$ Marisa Ionta, ${ }^{e}$ Daniela A. Chagas-Paula ${ }^{\circledR a}$ \\ and Danielle F. Dias ${ }^{\circledR} *, a$ \\ Instituto de Química, Universidade Federal de Alfenas, 37130-001 Alfenas-MG, Brazil \\ ${ }^{b}$ Escola de Farmácia, Universidade Federal de Ouro Preto, 35400-000 Ouro Preto-MG, Brazil \\ ${ }^{c}$ Faculdade de Ciências Farmacêuticas, Universidade Federal de Alfenas, 37130-001 Alfenas-MG, Brazil \\ ${ }^{d}$ Departamento de Química, Universidade Federal de Viçosa, 36570-900 Viçosa-MG, Brazil \\ eInstituto de Ciências Biomédicas, Universidade Federal de Alfenas, 37130-001 Alfenas-MG, Brazil

\begin{abstract}
Considering the promising antitumor effects of compounds with dual anti-inflammatory and antiproliferative activities, thus benzophenones analogs (2-7) were evaluated on in vivo antiinflammatory assay and molecular docking analysis. Those with the best molecular docking results were in vitro evaluated on cyclooxygenase $(\mathrm{COX})$ enzymes and tested regarding antiproliferative activity. All derivatives displayed in vivo anti-inflammatory activity. Among them, the substances 2 '-hydroxy-4'-benzoylphenyl- $\beta$ - $D$-glucopyranoside (4), 4-hydroxy-4'-methoxybenzophenone (5) and 4'-(4"'-methoxybenzoyl)phenyl- $\beta$ - $D$-glucopyranoside (7) showed the best values of Glide Score in COX-2 docking evaluation and $\mathbf{4}$ and $\mathbf{5}$ selectively inhibited COX-2 and COX-1 in vitro enzymatic assay, respectively. Thus, $\mathbf{4}$ and $\mathbf{5}$ were tested against breast cancer (MCF-7, MDA-MB-231, Hs578T) and non-small-cell-lung cancer (A549) cell lines. The estrogen-positive MCF-7 cell line was more responsive compared to other tested cell lines. They induced cell cycle arrest at G1/S transition in MCF-7 cell line once there was an increase in G0/G1 population with concomitant reduction of $\mathrm{S}$ population. The antiproliferative activity of these substances on MCF-7 was associated with their ability to inhibit cyclin E expression, a critical regulator of G1/S transition. Taken together, the data indicate that $\mathbf{4}$ and $\mathbf{5}$ have dual anti-inflammatory and antiproliferative activities and support further studies to evaluate their antitumor potential.
\end{abstract}

Keywords: molecular docking, ear edema, breast cancer, MCF-7, triple-negative

\section{Introduction}

Chronic inflammation is associated with different pathological processes including cancer development and cancer progression. ${ }^{1,2}$ The constant exposure to inflammatory mediators such as arachidonic acid metabolites, cytokines, chemokines, and free radicals can contribute to uncontrolled cell proliferation, mutagenesis,

*e-mail: danielle.dias@unifal-mg.edu.br

\#Contributed equally to this work: Laís R. S. Folquitto and Thiago B. Souza.

Editor handled this article Teodoro S. Kaufman and Brenno A. D. Neto (Associated) angiogenesis, and activation of oncogenic pathways. ${ }^{3,4}$ Nonsteroidal anti-inflammatory drugs (NSAIDs) have demonstrated potential in the prevention and treatment of cancer ${ }^{2}$ and maybe incorporated in chemotherapy and radiotherapy regimens. ${ }^{5}$ Besides cancer, other diseases are also associated with inflammation, which arouses interest in anti-inflammatory drug screening since the available NSAIDs have recognized side effects and limited efficacy in many of these cases. ${ }^{6-8}$

Ketoprofen is a potent NSAID with excellent analgesic properties. It possesses a diphenylmethanone nucleus (benzophenone) and acts by inhibiting prostaglandin synthesis, as well as by inhibiting both forms of 
cyclooxygenase (COX-1 and COX-2). ${ }^{9}$ It is effective and generally well-tolerated in a variety of inflammatory disorders, including osteoarthritis and rheumatoid arthritis. ${ }^{10}$ Studies with ketoprofen have, in general, showing that it has efficacy equivalent to or greater than that of other NSAIDs. ${ }^{11}$ Moreover, increased anti-inflammatory activity and high selectivity for COX-2 have been described for new ketoprofen derivatives. Some ketoprofenamides with a heterocycle have exhibited significant analgesic and anti-inflammatory activities when compared to the parent drug. ${ }^{12}$ In this context, the diphenylmethanone nucleus has been shown to be a versatile pharmacophore group. ${ }^{13-16}$

It has been reported that compounds containing carbohydrates in their structure display various pharmacological activities, including anti-inflammatory and cytotoxic effects. The presence of a saccharide moiety has been shown to be important in improving drug solubility, stability, and/or interaction with the receptor. ${ }^{17}$ Therefore, the synthesis of benzophenone derivatives containing carbohydrate units has gained considerable interest regarding the evaluation of their potential as new anti-inflammatory drugs..$^{18}$ As mentioned before, benzophenones have potent anti-inflammatory activity, and the presence of carbohydrates in the structure may ultimately help to facilitate their interaction with the molecular target and improve their pharmacokinetic properties. ${ }^{19-21}$ In addition, some glucoside derivatives have also shown anticancer activity ${ }^{22,23}$ and antiinflammatory potential. ${ }^{18}$ Thus, the development of new glucosides with dual anti-inflammatory and anti-cancer properties would be extremely relevant to the search for new clinically effective prototypes. Benzophenone glucosides can be synthesized using a classical method of reaction between the phenol and the base on the per-acetylglucosyl bromide, or by glucosylation of phenols through phase transfer, as an option possible with high yield. ${ }^{24-26}$ In the present work, innovative glucosides benzophenones were synthesized by these two methods (Figure 1) aiming to identify substances with dual anti-inflammatory and antiproliferative activities. Aglycone benzophenone precursors also were considered in this investigation. The glucosylated derivative $\mathbf{4}$ and the aglycone $\mathbf{5}$ displayed significant anti-inflammatory activity and selectively inhibited COX-2 and COX-1, respectively. The same substances inhibited cell proliferation in estrogenpositive breast MCF-7 cells due to their ability to modulate cyclin E expression and induce cell cycle arrest at G1/S transition.

\section{Experimental}

\section{General}

Reagents, compound 2, and Amberlite ${ }^{\circledR}$ IR120 resin (Supelco-06428) were purchased from Sigma-Aldrich (Saint Louis, MO, USA). All melting point determinations were measured on a PFM-II Aaker apparatus and were not corrected. Infrared (IR) spectroscopy was performed on a Nicolet-iS50 spectrometer (Thermo Scientific, USA). Nuclear magnetic resonance (NMR) spectra were recorded on an AVANCE DRX $300 \mathrm{MHz}$ spectrometer (300 $\mathrm{MHz}$ for ${ }^{1} \mathrm{H}$ NMR and $75 \mathrm{MHz}$ for ${ }^{13} \mathrm{C}$ spectra,

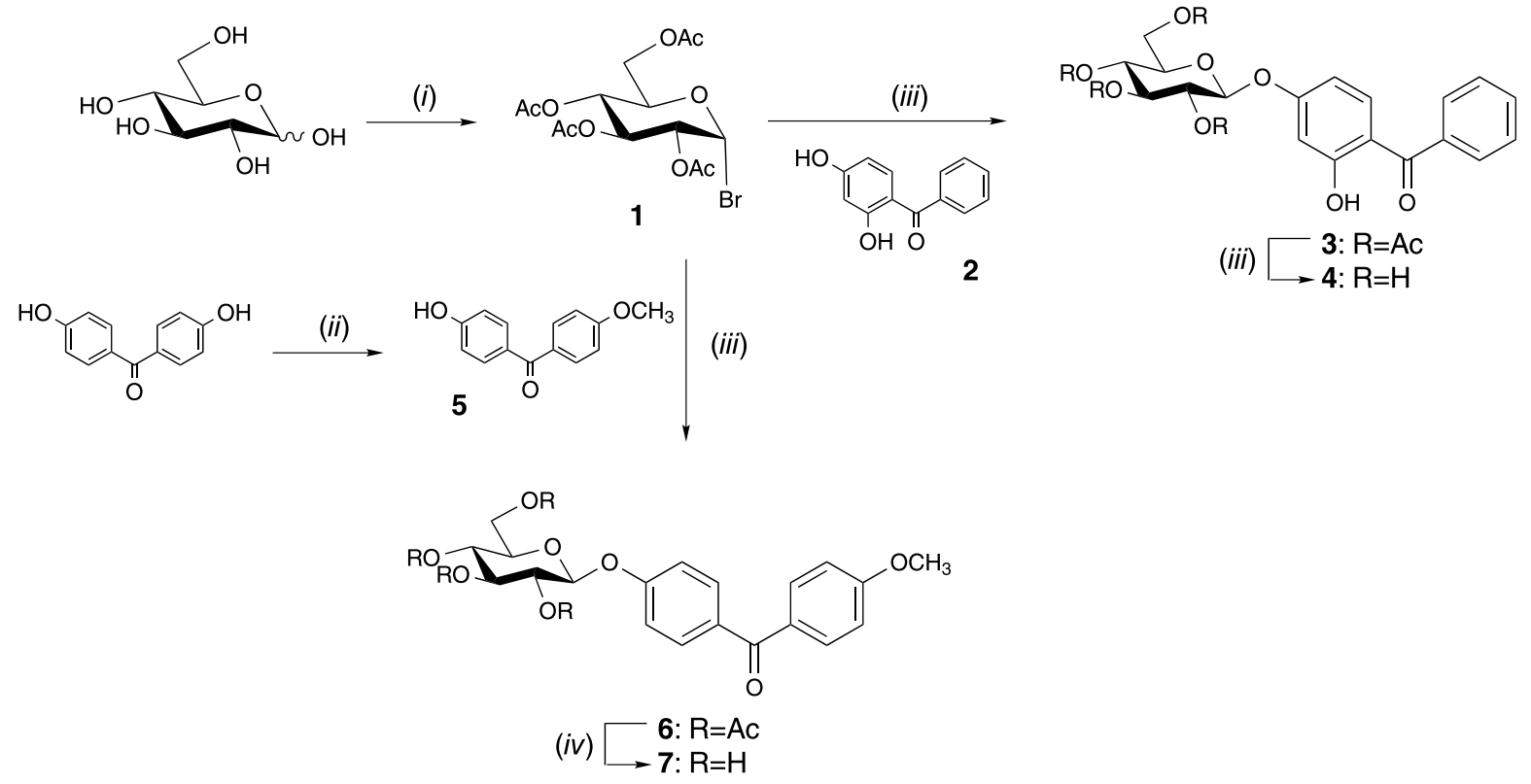

Figure 1. Synthesis of benzophenone glucosides. Reagents and conditions (i) (a) acetic anhydride, $\mathrm{H}_{2} \mathrm{SO}_{4}$, ultrasound bath, (b) acetic anhydride, $\mathrm{HBr}$, dichloromethane; (ii) acetone, $\mathrm{Na}_{2} \mathrm{CO}_{3}$, iodomethane; (iii) method A: corresponding benzophenone, LiOH, acetone, r.t.; method B: corresponding benzophenone, $\mathrm{K}_{2} \mathrm{CO}_{3}, \mathrm{~N}\left(\mathrm{Bu}_{4}\right) \mathrm{Br}$, dichloromethane; (iv) $\mathrm{MeOH}, \mathrm{KOH}, 0{ }^{\circ} \mathrm{C}$. 
Bruker, Germany) using deuterated chloroform or dimethyl sulfoxide (DMSO) from Cambridge Isotope Laboratories (Inc-Andover, MA, USA). The results are presented as chemical shifts $(\delta)$ reported in parts per million (ppm) with reference to tetramethylsilane (Sigma-Aldrich, Saint Louis, MO, USA) as the internal standard. Coupling constants $(J)$ were reported in hertz $(\mathrm{Hz})$ and the following abbreviations were used for the ${ }^{1} \mathrm{H}$ multiplicities: singlet (s), doublet $(\mathrm{d})$, double doublet $(\mathrm{dd})$, triplet $(\mathrm{t})$, triple triplet $(\mathrm{tt})$, and multiplet $(\mathrm{m})$. Reaction courses and product mixtures were monitored by thin-layer chromatography (TLC) on commercial silica gel 60 plates DC-Fertigfolien ALUGRAM $^{\circledR}$ Xtra SIL G/UV254 (Düren, Germany). Column chromatography purifications were performed over silica gel 60, 70-230 mesh (Sigma-Aldrich, Saint Louis, MO, USA). The specific optical rotation $[\alpha]_{D}$ was measured on a PerkinElmer 341 polarimeter (PerkinElmer Inc., Waltham, MA, USA), at $20^{\circ} \mathrm{C}$. The mass spectrometer contained an electrospray ionization (ESI) source and an Orbitrap technology analyzer (Thermo Fisher Scientific, USA) was used to record the high-resolution mass spectra (HRMS). Low-resolution mass spectra were acquired using a quadrupole mass spectrometer (Shimadzu, Kyoto, Japan) and the samples were solubilized in $\mathrm{MeOH} 0.1 \%$ formic acid, following manual injection.

\section{Synthesis of peracetylglucosyl bromide 1}

The $\alpha$ - $D$-glucosylbromide was synthesized previously described method ${ }^{27}$ by the D-glucose peracetylation and further reaction of the peracetylated glucose with hydrobromide acid (Fluka, St. Louis, USA) in acetic anhydride (Proquímicos, Rio de Janeiro, Brazil). Their spectra data were coherent with literature data. ${ }^{27}$

\section{Synthesis of 4-hydroxy-4'-methoxybenzophenone $\mathbf{5}$}

To a solution of 4,4'-dihydroxybenzophenone $(9.3 \mathrm{mmol})$ in acetone $(10 \mathrm{~mL})$ (Synth, Diadema, SP, Brazil) was added $\mathrm{Na}_{2} \mathrm{CO}_{3}(9.3 \mathrm{mmol})$ (FMaia Indústria e Comércio Ltda, BH, Brazil) and the mixture was stirred at room temperature for $20 \mathrm{~min}$. After this time, iodomethane (Sigma-Aldrich, Saint Louis, MO, USA) was added $(9.3 \mathrm{mmol})$ and the completion of the reaction was noted after $1 \mathrm{~h}$ by TLC. The acetone was evaporated, and the resulting product was partitioned into $10 \% \mathrm{NaOH}$ (FMaia Indústria e Comércio Ltda, $\mathrm{BH}$, Brazil) solution in water $(\mathrm{m} / \mathrm{v})$ and dichloromethane (Synth, Diadema, SP, Brazil). The basic layer was acidified to $\mathrm{pH} 1$, extracted with dichloromethane and this new organic layer was washed with water, dried over anhydrous $\mathrm{Na}_{2} \mathrm{SO}_{4}$ (FMaia Indústria e Comércio Ltda, BH, Brazil), and concentrated under reduced pressure. The product of interest was isolated from the crude product by column chromatography (hexane/ ethyl acetate; Synth, Diadema, SP, Brazil), with a yield of $21 \%$. Their spectra data were coherent with literature data. ${ }^{28}$

General procedure for the synthesis of glucosides $\mathbf{3}$ and $\mathbf{6}$

The glucosides 3 and $\mathbf{6}$ were synthesized by method A ("Reaction with glucosylbromide, phenol and base-method A" sub-section) and method B ('Reaction with phase transfer-method B" sub-section) to a comparison of yield in each method.

Reaction with glucosylbromide, phenol and base-method $A^{25}$

To a solution of peracetylglucosyl bromide (1, $1.7 \mathrm{mmol}$ ) in acetone (Synth, Diadema, SP, Brazil) was added $5 \mathrm{~mL}$ of an aqueous solution of the corresponding benzophenone (5.1 mmol) (Sigma-Aldrich, Saint Louis, MO, USA) and LiOH (4.6 mmol) (Sigma-Aldrich, Saint Louis, MO, USA) and the mixture was stirred at room temperature for $3 \mathrm{~h}$, when the completion of the reaction was confirmed by TLC. The acetone was evaporated, and the resulting product was extracted with dichloromethane. The obtained organic layer was washed with $\mathrm{HCl} 10 \%$ and water until $\mathrm{pH} 7$ was attained, then dried over anhydrous $\mathrm{Na}_{2} \mathrm{SO}_{4}$ and concentrated under reduced pressure. The crude product was purified by recrystallization from isopropyl alcohol (Synth, Diadema, SP, Brazil).

\section{Reaction with phase transfer-method $\mathrm{B}^{24}$}

The corresponding benzophenone $(1 \mathrm{mmol})$ was solubilized in dichloromethane $(5 \mathrm{~mL})$ and to this solution was added $10 \% \mathrm{~K}_{2} \mathrm{CO}_{3}(10 \mathrm{~mL})$ (Proquímicos, Rio de Janeiro, Brazil) and the mixture was stirred at room temperature for $30 \mathrm{~min}$. After this time, it was added to a reaction flask containing tetrabutylammonium bromide (0.34 mmol) (Sigma-Aldrich, Saint Louis, MO, USA) and finally, the peracetylglucosyl bromide $(1.1 \mathrm{mmol})$ was solubilized in dichloromethane. The mixture was stirred at room temperature for $72 \mathrm{~h}$ when the end of the reaction was confirmed by TLC. The mixture was extracted with dichloromethane and the organic layer was washed with water until $\mathrm{pH} 7$, dried over anhydrous $\mathrm{Na}_{2} \mathrm{SO}_{4}$, and concentrated under reduced pressure. The crude product was purified by recrystallization from isopropyl alcohol.

General procedure for the synthesis of glucosides 4 and $\mathbf{7}$

The procedure was performed according to de Souza et al. ${ }^{29}$ The peracetylated glucosides ( 3 and $\mathbf{6}$, 
$0.2 \mathrm{mmol}$ ) were solubilized in a solution of $\mathrm{KOH}$ (FMaia Indúdtria e Comércio Ltda, Diadema, SP, Brazil) in $\mathrm{MeOH}$ (20 mL, $1 \mathrm{M}$ ) (Synth, Diadema, SP, Brazil) and stirred for $30 \mathrm{~min}$ at $0{ }^{\circ} \mathrm{C}$. The completion of the reaction was confirmed by TLC. The mixture was neutralized with $1 \mathrm{~g}$ of Amberlite ${ }^{\circledR}$ IR120 resin. After neutralization, the resin was filtered off and washed with methanol. The collected filtrate was concentrated under reduced pressure, yielding the deacetylated glucosides derivatives $\mathbf{4}$ and $\mathbf{7}$.

Chemical characterization of the compounds $3,4,6$ and 7

All the spectra data of IR, NMR, and mass (MS) are available in the Supplementary Information section (Figures S1-S16).

Chemical characterization of the 2'-hydroxy-4'-benzoylphenyl(2,3,4,6-tetra-O-acetyl- $\beta$ - $D$-glucopyranoside) (3)

This product was obtained in 18 and $54 \%$ yield (method A and $\mathrm{B}$, respectively) as white crystals after purified by recrystallization (isopropyl alcohol); $\mathrm{mp} 175-176{ }^{\circ} \mathrm{C}$; $[\alpha]_{D}-44\left(c 0.005, \mathrm{CHCl}_{3}\right)$; IR (ATR) $v / \mathrm{cm}^{-1} 2970$, 1740, 1626, 1599, 1578, 1446, 1209, 1032 (Figure S1); ${ }^{1} \mathrm{H}$ NMR (300 MHz, $\mathrm{CDCl}_{3}$, Figure S2) $\delta 12.48(1 \mathrm{H}, \mathrm{s}$, $\mathrm{OH}$ ), 7.64-7.47 (6H, m, H-6', H-2', H-3', H-4", H-5', H-6”), 6.62 (1H, d, H-3', J' 2.4 Hz), 6.46 (1H, dd, H-5', $\left.J^{3} 8.9, J^{4} 2.5 \mathrm{~Hz}\right), 5.32-5.18(4 \mathrm{H}, \mathrm{m}, \mathrm{H}-1, \mathrm{H}-2, \mathrm{H}-3$ and H-4), 4.27 (1H, dd, H-6, J $\left.12.2, J^{3} 5.9 \mathrm{~Hz}\right), 4.17$ (1H, dd, H-6, $J^{2} 12.2, J^{3} 2.4 \mathrm{~Hz}$ ), 3.94-3.91 (1H, m, H-5), 2.11-2.03 $\left(12 \mathrm{H}, \mathrm{s}, \mathrm{OCOCH}_{3}\right) ;{ }^{13} \mathrm{C} \mathrm{NMR}\left(75 \mathrm{MHz}, \mathrm{CDCl}_{3}\right.$, Figure S3) $\delta 200.2\left(1 \mathrm{C}, \mathrm{C}^{\prime} 7^{\prime}\right), 170.6-169.2$ (4C, ester $\left.\mathrm{C}=\mathrm{O}\right), 165.7$ (1C, C-2'), 162.5 (1C, C-4'), 137.9 (1C, C-1') 135.3 (1C, C-6'), 131.7 (1C, C-4"'), 128.8 (2C, C-2"' and C-6"), 128.3 (2C, C-3" and C-5"), 114.7 (1C, C-1'), 108.4 (1C, C-5'), 104.0 (1C, C-3'), 97.7 (1C, C-1), 72.5 (1C, C-5), 72.3 (1C, C-3), 70.8 (1C, C-2), 68.1 (1C, C-4), 61.8 (1C, C-6), $20.5\left(4 \mathrm{C}, \mathrm{OCOCH}_{3}\right)$; high resolution mass-electrospray (HRMS-ESI) $m / z$, calcd. for $\mathrm{C}_{27} \mathrm{H}_{28} \mathrm{O}_{12}[\mathrm{M}+\mathrm{H}]^{+}:$545.1653, found: 545.1674, error: 2.1 ppm (Figure S4).

\section{Chemical characterization of the 2'-hydroxy-4'-benzoylphenyl- $\beta$-D-glucopyranoside (4)}

This product was obtained in $85 \%$ yield as white crystals; mp $116-118^{\circ} \mathrm{C}$; $[\alpha]_{D}-56$ (c 0.005, MeOH); IR (ATR) $v / \mathrm{cm}^{-1} 3314,2899,1639,1599,1576,1448,1236$ (Figure S5); ${ }^{1} \mathrm{H}$ NMR (300 MHz, DMSO- $d_{6}$, Figure S6) $\delta$ 7.65-7.51 (5H, m, H-2", H-3", H-4", H-5", H-6"), 7.40 (1H, d, H-6', J' $7.4 \mathrm{~Hz}), 6.64-6.60$ (2H, m, H-3' and H-5'), 4.97 (1H, d, H-1, J3 7.3 Hz), 3.71-3.18 (6H, m, H-2, $\mathrm{H}-3, \mathrm{H}-4, \mathrm{H}-5$ and H-6); ${ }^{13} \mathrm{C}$ NMR (75 MHz, DMSO- $d_{6}$, Figure S7) $\delta 198.8$ (1C, C-7'), 163.1 (1C, C-2'), 162.7
(1C, C-4'), 138.0 (1C, C-1'”), 134.4 (1C, C-6'), 132.4 (1C, C-4"), 129.1 (2C, C-2" and C-6"), 128.8 (2C, C-3" and C-5"), 115.9 (1C, C-1'), 108.4 (1C, C-1), 104.0 (1C, C-5'), 100.0 (1C, C-3'), 77.3 (1C, C-5), 76.6 (1C, C-3), 73.3 (1C, C-2), 69.8 (1C, C-4), 60.8 (1C, C-6); MS-ESI $\mathrm{m} / z$, calcd. for $\mathrm{C}_{19} \mathrm{H}_{20} \mathrm{O}_{8}[\mathrm{M}+\mathrm{Na}]^{+}:$399.1, found: 399.1 (Figure S8).

Chemical characterization of the 4'-(4"-methoxybenzoyl) phenyl-(2,3,4,6-tetra-O-acetyl- $\beta$ - $D$-glucopyranoside) (6)

This product was obtained in 25 and $51 \%$ yield (method $A$ and $\mathrm{B}$, respectively) as white crystals after purified by recrystallization (isopropyl alcohol); $\mathrm{mp} 171-172^{\circ} \mathrm{C}$; $[\alpha]_{D}-28\left(c 0.005, \mathrm{CHCl}_{3}\right)$; IR (ATR) v / $\mathrm{cm}^{-1} 2944,1743$, 1634, 1601, 1507, 1367, 1203, 1031 (Figure S9); ${ }^{1} \mathrm{H}$ NMR (300 MHz, $\mathrm{CDCl}_{3}$, Figure S10) $\delta$ 7.79-7.74 (4H, m, H-2', H-6', H-2', and H-6'"), 7.04 (2H, dd, H-3' and H-5', $\left.J^{3} 6.8, J^{4} 2.0 \mathrm{~Hz}\right), 6.95\left(2 \mathrm{H}, \mathrm{dd}, \mathrm{H}-3\right.$ "' and $\mathrm{H}-5$ ", $J^{3} 6.8$, $J^{4} 2.0 \mathrm{~Hz}$ ), 5.33-5.18 (4H, m, H-1, H-2, H-3 and H-4), 4.29 (1H, dd, H-6, $J^{2} 12.3, J^{3} 5.3 \mathrm{~Hz}$ ), 4.17 (1H, dd, H-6, $\left.J^{2} 12.3, J^{3} 2.4 \mathrm{~Hz}\right), 3.94-3.88$ (1H, m, H-5), 3.88 (3H, s, H-7") ), 2.07-2.04 (12H, s, OCOC $\left.\underline{\mathrm{H}}_{3}\right) ;{ }^{13} \mathrm{C} \mathrm{NMR} \mathrm{(75} \mathrm{MHz,}$ $\mathrm{CDCl}_{3}$, Figure S11) $\delta 194.2$ (1C, C-7'), 170.5-169.2 (4C, ester C=O), 163.1 (1C, C-4"'), 159.5 (1C, C-4'), 133.2 (1C, C-1"), 132.3 (2C, C-2" and C-6"), 131.9 (2C, C-2' and C-6'), 130.2 (1C, C-1'), 116.0 (2C, C-3' and C-5'), 113.5 (2C, C-3" and C-5"), 98.3 (1C, C-1), 72.6 (1C, C-5), 72.2 (1C, C-3), 71.0 (1C, C-2), 68.2 (1C, C-4), 61.9 (1C, C-6), 55.5 (1C, C-7'), 20.6 (4C, $\left.\mathrm{OCOCH}_{3}\right)$; HRMS-ESI $\mathrm{m} / \mathrm{z}$, calcd. for $\mathrm{C}_{28} \mathrm{H}_{30} \mathrm{O}_{13}[\mathrm{M}+\mathrm{H}]^{+}:$559.1810, found: 559.1815, error: 0.9 (Figure $\mathrm{S} 12$ ).

Chemical characterization of the 4'-(4"-methoxybenzoyl) phenyl- $\beta-D$-glucopyranoside (7)

This product was obtained in $96 \%$ yield as yellow crystals; mp $162-164{ }^{\circ} \mathrm{C} ;[\alpha]_{D}-48$ (c $\left.0.005, \mathrm{MeOH}\right)$; IR (ATR) $v / \mathrm{cm}^{-1} 3359,2915,1651,1596,1511,1465$ (Figure S13); ${ }^{1} \mathrm{H}$ NMR (300 MHz, DMSO- $d_{6}$, Figure S14) $\delta$ 7.74-7.67 (4H, m, H-2', H-3', H-5' and H-6'), 7.17 (2H, d, H-2" and H-6", $\left.J^{3} 9.0 \mathrm{~Hz}\right), 7.08$ (2H, d, H-3" and H-5", $\left.J^{3} 8.7 \mathrm{~Hz}\right), 5.02$ (1H, d, H-1, $\left.J^{3} 7.2 \mathrm{~Hz}\right), 3.86(3 \mathrm{H}$, s, H-7"), 3.71 (1H, d, H-6, $\left.J^{2} 11.1 \mathrm{~Hz}\right), 3.50-3.37$ (2H, m, sugar, H-5 and H-6), 3.30-3.18 (3H, m, sugar, H-2, H-3, $\mathrm{H}-4) ;{ }^{13} \mathrm{C}$ NMR (75 MHz, DMSO- $d_{6}$, Figure S15) $\delta 193.3$ (1C, C-7'), 162.7 (1C, C-4'”), 160.5 (1C, C-4'), 131.9 (2C, C-2" and C-6"), 131.6 (2C, C-2' and C-6'), 131.1 (1C, C-1'"), 129.9 (1C, C-1'), 115.8 (2C, C-3' and C-5'), 113.8 (2C, C-3" and C-5"), 99.9 (1C, C-1), 77.18 (1C, C-5), 76.5 (1C, C-3), 73.2 (1C, C-2), 69.6 (1C, C-4), 60.6 (1C, C-6), 55.5 (1C, C-7"); HRMS-ESI calculated $\mathrm{m} / \mathrm{z}$, calcd. for $\mathrm{C}_{20} \mathrm{H}_{22} \mathrm{O}_{8}[\mathrm{M}+\mathrm{H}]^{+}:$391.1387, found: 391.1391, error: 0.8 ppm (Figure S16). 


\section{Animals}

The animal experiment was approved by the Ethics Committee of the Federal University of Alfenas (506/2013). The adult male Swiss mice weighing 28-32 g, obtained from the Central Animal Facility of the Federal University of Alfenas, were housed under controlled light $(12 / 12 \mathrm{~h}$ light-dark cycle) and temperature conditions $\left(23 \pm 1{ }^{\circ} \mathrm{C}\right)$ with access to water and food ad libitum.

\section{Croton oil-induced ear edema}

Ear inflammation in the mouse was produced as described previously. ${ }^{30,31}$ The assay was done using 7 animals per group of the substances or positive controls: ketoprofen and indomethacin (Sigma-Aldrich, Saint Louis, MO, USA). The substances and positive controls were administered orally $1 \mathrm{~h}$ before the application of $20 \mu \mathrm{L}$ croton oil solution (SigmaAldrich, Saint Louis, MO, USA; $5 \% \mathrm{v} / \mathrm{v}$ in acetone) to the inner surface of each left ear and $20 \mu \mathrm{L}$ of acetone to the right ear as a control. All samples, substances (aglycones $\mathbf{2}$ and $\mathbf{5}$, and the derivatives $3,4,6$, and 7), and positive controls were administered in the same dose $(0.5 \mathrm{mg}$ per ear) according to established protocols. ${ }^{30,32,33}$ Edema was measured $6 \mathrm{~h}$ after starting the experiment, determined as the weight difference between $6 \mathrm{~mm}$ plugs taken from the left and right ears. The data are expressed as mean \pm standard error of the mean (SEM) and were analyzed by one-way analysis of variance (ANOVA) followed by the Newman-Keuls post-hoc test. $P$-values $<0.05(P<0.05)$ were considered significant.

\section{Molecular modeling}

The structures of the ligands, indomethacin and ketoprofen (standard drugs used in the pharmacological and experimental evaluations) were constructed using Maestro 9.2. ${ }^{34}$ The software LigPrep $2.5^{35}$ was used for the construction and preparation of the ligands involved in these studies. The crystallographic structures of cyclooxygenase 1 (COX-1) (Protein Data Bank (PDB) ID: 2OYU) and cyclooxygenase 2 (COX-2) (PDB ID: 3NT1) were obtained from the database PDB and the software Prime $3.0^{36}$ was used for the preparation of this enzymes. The OPLS 2005 force field in the MacroModel $9.9^{37}$ was used for optimization. Studies of molecular docking between COX-1 and COX-2 and the ligands were performed using the program Induced Fit Docking. ${ }^{38}$ All computer programs belong to the Schrödinger suite.

\section{Cyclooxygenase assay}

Substances 4, 5, and $\mathbf{7}$ were evaluated using a COX-1 and
COX-2 (catalog No. 560101 Cayman Chemical, Ann Arbor, MI, USA) screening kit, according to the manufacturer's instructions and established protocol. ${ }^{39}$ Ketoprofen was evaluated as the reference inhibitor for COX-1 and COX-2, and the vehicle was evaluated as the negative control. All substances were evaluated in the following concentrations: $0.01,1,10$, and $100 \mu \mathrm{M}$ in the final reaction volume. The concentration of each compound causing a $50 \%$ inhibition $\left(\mathrm{IC}_{50}, \mu \mathrm{M}\right)$ was calculated from the concentration-inhibition response curve, with data collected in triplicate.

\section{Antiproliferative evaluation}

Cell lines, culture conditions and treatment schedule

Non-small-cell lung cancer (A549) cell line and breast cancer MCF-7 (estrogen-positive), Hs578T (triple-negative), and MDA-MB-231 (triple-negative) cell lines were used in the present study. These cell lines were purchased from the Rio de Janeiro cell bank (Rio de Janeiro, RJ, Brazil). Cell cultures were maintained in Dulbecco's Modified Eagle's Medium (DMEM/F12, Sigma-Aldrich, CA, USA) supplemented with $10 \%$ fetal bovine serum (Vitrocell, Campinas, Brazil). Peripheral blood mononuclear cells (PBMC) were also used as the reference of normal cells and were maintained in RPMI (Roswell Park Memorial Institute) medium (SigmaAldrich, Saint Louis, MO, USA) supplemented with $10 \%$ fetal bovine serum. Cells were grown in a $37{ }^{\circ} \mathrm{C}$ humidified incubator (Thermo Fisher Scientific, Waltham, Massachusetts, USA), containing $5 \% \mathrm{CO}_{2}$. Studied compounds were solubilized in dimethyl sulfoxide (DMSO; Sigma, Saint Louis, MO, USA) to obtain a stock solution, which was subsequently diluted in fresh medium at the appropriate concentrations immediately before use. Vehicle alone was used as the control and the final concentration of the solvent did not exceed $0.5 \%(\mathrm{v} / \mathrm{v})$. The cell cultures were treated for $48 \mathrm{~h}$ with the different substances.

\section{Cell viability assay}

Cell viability was assessed in tumor and normal cells according to well-established protocols. ${ }^{40,41}$ Cells were seeded into 96-well flat-bottom plates at a density of $5 \times 10^{3}$ cells well ${ }^{-1}$ or $1 \times 10^{4}$ cells well ${ }^{-1}$ depending on the cell line. Cell cultures were treated with substances 4 or 5 (concentration range $0-500 \mu \mathrm{M}$ ) for $48 \mathrm{~h}$. Ketoprofen and cisplatin (Sigma-Aldrich, Saint Louis, MO, USA) were used as controls. All experiments were conducted in quadruplicate wells, and the data are presented as median \pm standard deviation (SD) of three independent experiments. Viable cells with active metabolism can reduce resazurin (absorption peak at $600 \mathrm{~nm}$ ) into the 
resorufin product (absorption peak at $570 \mathrm{~nm}$ ). Cell viability analysis was performed previously. ${ }^{42}$ Significant differences from the control group (DMSO) were determined using ANOVA followed by Tukey's post-hoc test.

\section{Cell cycle analysis}

Cell cycle analysis was performed according to Ferreira-Silva et al. ${ }^{43}$ Briefly, cells were treated with $\mathbf{4}$ and 5 for $48 \mathrm{~h}$ in concentrations equivalent to $\mathrm{IC}_{50}$ values. Cells were fixed with $75 \%$ ethanol (Sigma-Aldrich, Saint Louis, MO, USA) at $4{ }^{\circ} \mathrm{C}$ overnight, rinsed twice with cold phosphate-buffered saline (PBS). Afterward, cells were homogenized in dye solution (PBS containing $90 \mu \mathrm{g} \mathrm{mL}^{-1}$ propidium iodide (PI) and $3 \mathrm{mg} \mathrm{mL}^{-1}$ RNAase) (SigmaAldrich, Saint Louis, MO, USA), and deoxyribonucleic acid (DNA) was quantified $1 \mathrm{~h}$ after staining. The analysis was performed using a flow cytometer (Guava easyCyte 8HT, Luminex, Austin, Texas, USA). Results are presented as mean \pm SD of three independent experiments. Significant differences from the control group (DMSO) were determined using ANOVA followed by Tukey's post-hoc test.

\section{Immunoblot}

Cells were homogenized in RIPA lysis buffer $(150 \mathrm{mM} \mathrm{NaCl}, 1.0 \%$ Nonidet P-40, 0.5\% deoxycholate, $0.1 \%$ sodium dodecyl sulfate (SDS), and $50 \mathrm{mM}$ Tris $\mathrm{pH}$ 8.0) containing both protease and phosphatase inhibitors (Sigma-Aldrich, Saint Louis, MO, USA). Lysates were centrifuged $(10,000 \times \mathrm{g})$ for $10 \mathrm{~min}$ at $4{ }^{\circ} \mathrm{C}$. Supernatants were recovered, then total proteins were quantified (BCA kit, Pierce Biotechnology Inc., Rockford, IL, USA) and resuspended in Laemmli sample buffer containing $62.5 \mathrm{mM}$ Tris- $\mathrm{HCl} \mathrm{pH} 6.8,2 \%$ SDS, $10 \%$ glycerol, $5 \%$ 2-mercaptoethanol, and $0.001 \%$ bromophenol blue (SigmaAldrich, Saint Louis, MO, USA). An aliquot of $30 \mu \mathrm{g}$ protein was separated by SDS-PAGE (12\%) and transferred (100 V, $250 \mathrm{~mA}$ for $2 \mathrm{~h}$ ) onto a polyvinylidene difluoride (PVDF) membrane (Cytiva, São Paulo, Brazil), which was then blocked for $1 \mathrm{~h}$ at $4{ }^{\circ} \mathrm{C}$ with blocking solution $(5 \%$ non-fat milk (Nestlé, São Paulo, Brazil) in Tris-buffered saline (TBS) $+0.1 \%$ (v/v) Tween-20 (Sigma-Aldrich, Saint Louis, MO, USA)) to prevent nonspecific protein binding. The membrane was probed with primary antibodies: cyclin E (1:200) and $\alpha$-tubulin (Sigma-Aldrich, Saint Louis, MO, USA, 1:1000) overnight at $4{ }^{\circ} \mathrm{C}$. After washing with TBS-Tween $(0.1 \%)$, the membrane was incubated with a secondary antibody (anti-mouse, peroxidase conjugated; Cytiva, São Paulo, Brazil) for $2 \mathrm{~h}$ at room temperature. Immunoreactive bands were visualized with the ECL Western Blotting Detection Kit (Cytiva, São Paulo, Brazil). A reprobing protocol was followed for detecting immunoreactive bands for different antibodies. The quantification of immunoreactive bands was performed.

\section{Results and Discussion}

\section{Chemistry}

The glucosides of benzophenones were synthesized following classical methods, as shown in Figure 1. There are different described glycosylation methods involving the reaction of a glucosyl donor that generates an electrophilic compound, which interacts with a nucleophilic reagent to form a glycosidic linkage with the first chemical entity. ${ }^{44}$ The development of improved methods of glycosylation is especially important and necessary due to the biological importance of these compounds. ${ }^{45}$ In this work, two different methods for the synthesis of glucosides of benzophenones were employed (Figure 1). The starting benzophenone 4-hydroxy-4'-methoxybenzophenone 5 was synthesized by the reaction of 4,4'-dihydroxybenzophenone and iodomethane, with a yield of $21 \%$. Initially, benzophenone glucosides were synthesized using a widely described classical method involving the nucleophilic attack of the phenoxide ion generated from the reaction between the phenol (corresponding benzophenone) and the base on the per-acetylglucosyl bromide. ${ }^{25,26}$ The glucosides $\mathbf{3}$ and 6 were obtained in yields ranging from 14 and $25 \%$ by this method (A).

Considering these low yield values, their synthesis was repeated employing another method for the glucosylation of phenols that used tetrabutylammonium bromide as a phase transfer-method B. ${ }^{24}$ The compounds synthesized by the phase transfer method were obtained in yields twice as high as those of the classical technique (54 and 51\% yields for $\mathbf{3}$ and $\mathbf{6}$, respectively). Ester and ketone bands in 1740 and $1743 \mathrm{~cm}^{-1}$, respectively, were observed in the IR spectra of these compounds (Figures S1 and S9, SI section). The acetylated glucosides' ${ }^{1} \mathrm{H}$ NMR spectra showed singlets corresponding to acetylic hydrogens near $2 \mathrm{ppm}$; signals relative to the aromatic hydrogens were registered between 7.81-6.46 ppm (Figures S2 and S10, SI section). The carbonyls of these compounds' benzophenone rings were recorded between 200.2-194.0 ppm, while acetylic carbonyls were registered around $170 \mathrm{ppm}$ in the ${ }^{13} \mathrm{C}$ NMR spectra (Figures S2 and S11, SI section).

All acetylated glucosides of benzophenones were deacetylated by stirring them in a potassium hydroxide/ methanol solution for $30 \mathrm{~min}$, affording yields around $85 \%$ to the unprotected glucosides 4 and $7 .{ }^{29}$ The IR spectra of these compounds did not show the ester bands registered for acetylated glucosides but, concomitantly, contained 
large bands close to $3300 \mathrm{~cm}^{-1}$ which correspond to the hydroxyl groups of deacetylated derivatives (Figures S5 and S13, SI section). As noted in the glucosides' ${ }^{1} \mathrm{H}$ NMR spectra, all of them were obtained as $\beta$-anomers (Figures S6 and S14, SI section). This was certified by the coupling constant of $7.3 \mathrm{~Hz}$ for the anomeric hydrogens, which was registered close to 5 ppm (Figures S6 and S14, SI section). Finally, only one carbonyl signal (benzophenone ring) was registered at $193-198 \mathrm{ppm}$ in the ${ }^{13} \mathrm{C}$ NMR spectra (Figures S7 and S15, SI section).

\section{Anti-inflammatory results}

The glucosylated derivatives 4, 6 and 7 effectively inhibited ear edema statistically similar to the starting benzophenones and the control drugs, all with $p<0.001$ compared to the negative control (vehicle). The acetylated derivative 3 also inhibited ear edema, but with $p<0.01$ compared to negative control. All the compounds were evaluated at the same dose $(0.5 \mathrm{mg}$ per ear) to assess antiinflammatory activity, which significantly inhibited edema according to one-way ANOVA followed by Newman-Keuls test (Figure 2). The values for edema inhibition for the free aglycones 2 and 5 were 55 and 53\%, respectively, while the glucosides displayed 51, 67, and 73\%, for 4, 6 and 7, respectively-statistically similar to the values found for the NSAIDs used as positive controls (62\% of inhibition for indomethacin and ketoprofen).

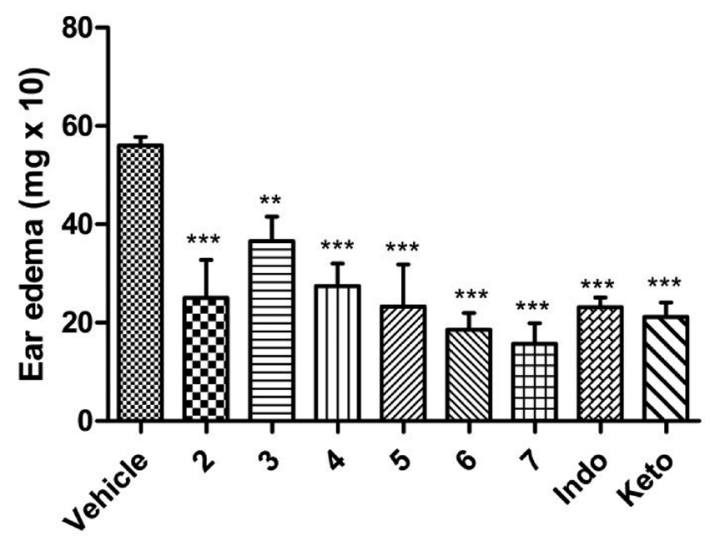

Figure 2. Effect of benzophenone glucosides on croton oil-induced ear edema in mice. The substances, ketoprofen (Keto) and indomethacin (Indo) ( $0.5 \mathrm{mg}$ per ear) were orally administered before the application of croton oil solution in acetone $(20 \mu \mathrm{L}$ per ear). Positive and negative control groups were significantly different. One-way analysis of variance (ANOVA) followed by Newman-Keuls test was employed. Data represent the mean \pm SEM of 7 animals $(* * p<0.01 ; * * * p<0.001)$.

\section{Molecular docking analyses}

In order to check the affinity profile of the synthesized compounds with cyclooxygenases 1 and 2 (COX-1,
COX-2), a docking study was carried out. ${ }^{46,47}$ The results of analysis of all compounds (2-7) showed Glide score (GScore) values between -14.245 and $-8.677 \mathrm{kcal} \mathrm{mol}^{-1}$ (Tables S1 and S2, SI section) and they suggest that these high affinities can lead to the inhibition of such isoenzymes.

The results (Tables $\mathrm{S} 1$ and $\mathrm{S} 2$ ) revealed that compounds 4, 5, and 7 presented better GScore values in docking molecular of COX-2 enzyme than the other compounds. Hydrogen bond interactions of each compound's greatest affinity conformations could be visualized in Figures 3 and 4.

It was observed that the glucosides presented better values of GScore than the non-glucosylated derivatives, which showed a smaller number of hydrophobic interactions (good van der Waals) and a low profile of liposolubility. Considering the glucosylated compounds, the non-acetylated substances (derivatives 4 and 7) presented better values of affinity compared to the acetylated derivatives (3 and $\mathbf{6}$ ). The acetylated derivative $\mathbf{3}$ did not present GScore results in molecular docking studies that could be related to its molecular volume, leading to a steric hindrance in relation to the size of the COX-2 active site and corroborating the results of the edema bioassay lower percentage of edema inhibition (35\%) compared to the other evaluated compounds.

The glucoside 4 presented the best value of Gscore for both isoenzymes $\left(\mathrm{COX}-1=-15.230 \mathrm{kcal} \mathrm{mol}^{-1}\right.$ and COX-2 $=-14.245 \mathrm{kcal} \mathrm{mol}^{-1}$ ), with higher values of affinity than those presented by the standards drugs, indomethacin and ketoprofen. Although compound 4 showed no selectivity between the two isoenzymes, the results of the molecular docking study are in accordance with the edema inhibition results $(51 \%)$. The glucosylated compound 7 presented the second-best GScore value for the two enzymes $\left(\mathrm{COX}-1=-14.169 \mathrm{kcal} \mathrm{mol}^{-1}\right.$ and COX-2 $\left.=-13.504 \mathrm{kcal} \mathrm{mol}^{-1}\right)$, and the aglycone 5 showed the third-best GScore value for COX-2 (-11.330 kcal mol $\left.{ }^{-1}\right)$. Thus, compounds $\mathbf{4 , 5}$, and $\mathbf{7}$ with better docking results were selected for in vitro evaluation on COX enzymes. The results of molecular docking showed that the other substances, as compound 6 , also have the potential to inhibit the COX-1 or COX-2 enzyme, thus, they may be evaluated in future studies.

\section{In vitro COX inhibition}

In this context, after anti-inflammatory assay and molecular docking, the glucosides $\mathbf{4}$ and $\mathbf{7}$ and the aglycone 5 were evaluated about the inhibition of the isoenzymes COX-1 and COX-2 (Table 1). Derivative 4 showed selective inhibition for COX-2 at $4 \mu \mathrm{M}$, while 7 was inactive for both isoforms. The presence of the 4-methoxy 


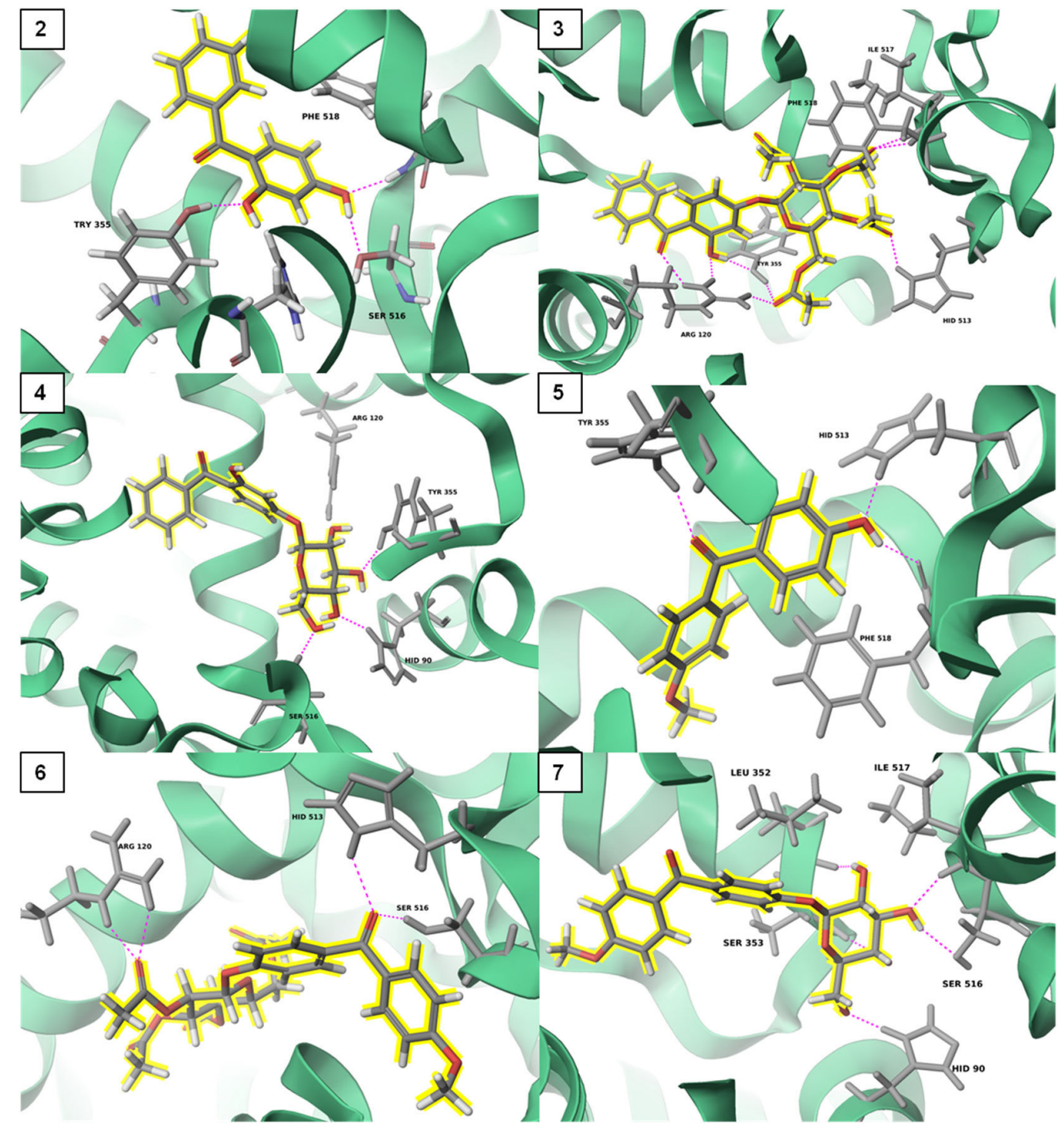

Figure 3. Representation of molecular docking results between ligands 2-7 and COX-1 enzyme.

group and the absence of a 2-hydroxy group in substance 7, compared to substance $\mathbf{4}$, seem to have been critical to abolish its activity on COX-2. Substance 5 selectively and moderately inhibited COX-1 at $67.25 \mu \mathrm{M}$.

Additionally, it was possible to determine that the edema inhibition caused by substance 7 was not a result of COX-1 or -2's direct inhibition, as demonstrated by the enzymatic findings. They may be due to its molecular volume leading to a possible steric hindrance to allow access to the enzyme active sites. These results suggest that these compounds could have an innovative mechanism of action that deserves further investigation.

\section{Antiproliferative activity}

The antiproliferative potential of the substances $\mathbf{4}$ and $\mathbf{5}$ was evaluated against tumor cell lines derived from human breast cancer (MCF-7, Hs578T, and MDA-MB-231) and non-small cell lung cancer (A549). Cell viability was assessed after $48 \mathrm{~h}$ of treatment and $\mathrm{IC}_{50}$ values were determined (Table 2). The data showed that MCF-7 cells were the most responsive for both substance $\mathbf{4}$ and $\mathbf{5}$ compared to other evaluated tumor cells. The $\mathrm{IC}_{50}$ values found for these substances on MCF-7 were lower than those found for ketoprofen; but higher compared to cisplatin, a powerful cytotoxic agent. In addition, substances $\mathbf{4}$ and $\mathbf{5}$ displayed low cytotoxic activity on PBMC, which were included in this study to evaluate the effects of these substances on normal cells.

Based on previous findings, MCF-7 was selected for further investigation to verify whether the reduction in cell viability promoted by substances $\mathbf{4}$ and $\mathbf{5}$ could be associated with their ability to inhibit cell proliferation; however, it is important to note that substances $\mathbf{4}$ and $\mathbf{5}$ 


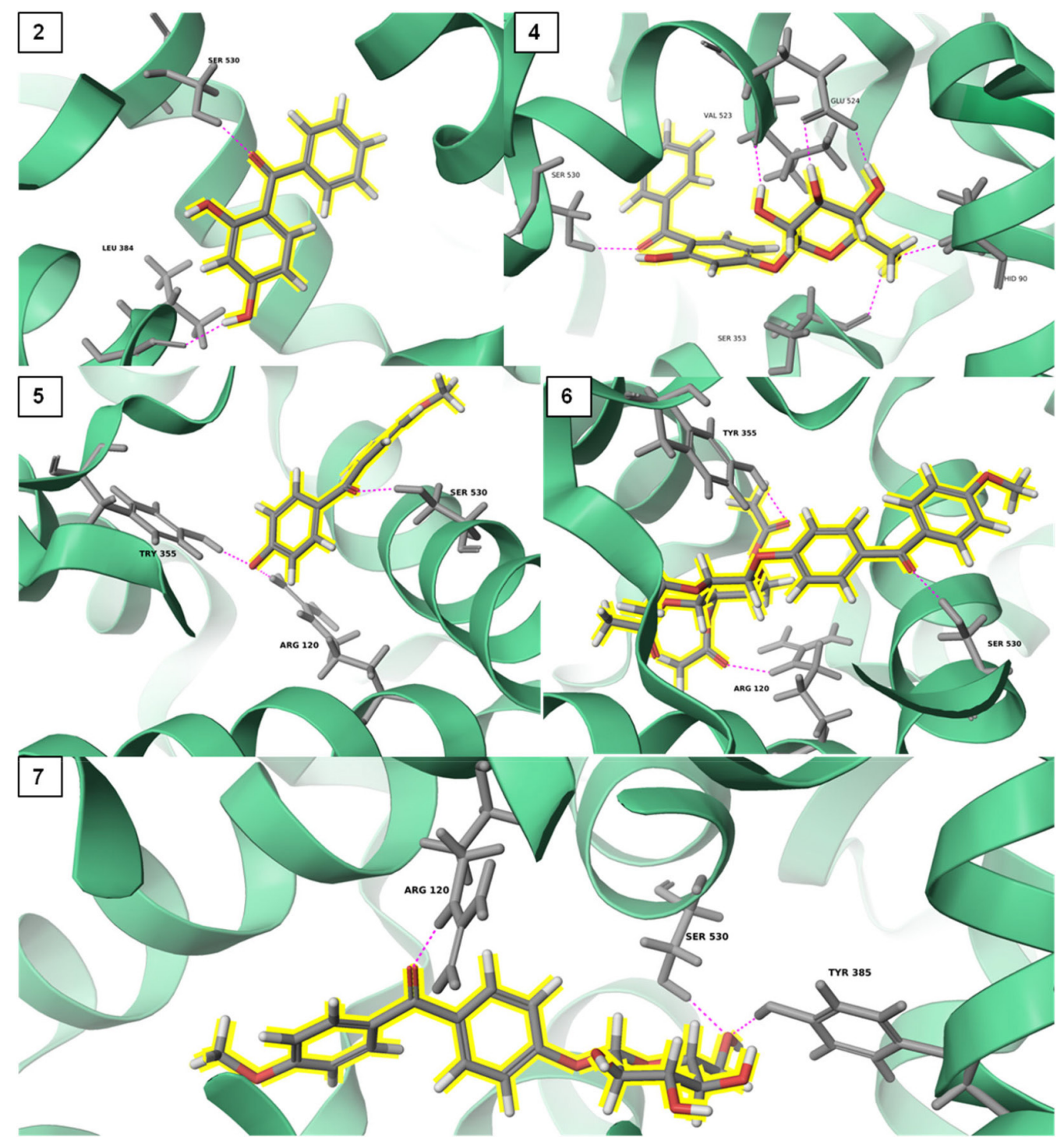

Figure 4. Representation of molecular docking results between ligands 2, 4-7 and COX-2 enzyme.

Table 1. Half maximal inhibitory concentration $\left(\mathrm{IC}_{50}\right)$ values of in vitro cyclooxygenase- 1 and -2 (COX-1 and COX-2, respectively) enzyme inhibition

\begin{tabular}{lcc}
\hline \multirow{2}{*}{ Compound } & \multicolumn{2}{c}{$\mathrm{IC}_{50} / \mu \mathrm{M}$} \\
\cline { 2 - 3 } $\mathbf{4}$ & $\mathrm{COX}-1$ & $\mathrm{COX}-2$ \\
$\mathbf{5}$ & $>100$ & 4.0 \\
$\mathbf{7}$ & 67.25 & $>100$ \\
Ketoprofen & $>100$ & $>100$ \\
\hline
\end{tabular}

had an interesting effect on Hs578T and MDA-MB-231, respectively. These cell lines are representative of triplenegative breast cancer, a subtype of breast cancer treated preferentially with cytotoxic chemotherapy due to the absence of therapeutic targets. The drug arsenal for triplenegative breast cancer treatment is extremely limited and the patients frequently develop resistance to currently available drugs. ${ }^{48,49}$

In the next step, cell cycle analysis was performed to investigate a possible interference of the substances 4 and 5 on MCF- 7 cell cycle progression after $48 \mathrm{~h}$ of the treatment. Cell cultures were photographed immediately before the cell cycle analysis to evidence morphological features of MCF-7 cells. The morphological pattern of cells treated with $\mathbf{4}$ was similar to observed in control cultures, however, the samples treated with $\mathbf{5}$ exhibited rounded cells or shrinkage cells (Figure 5a) indicating a cytotoxic effect of this compound on MCF-7 cells. Indeed, flow cytometry data showed that sub-G1 populations (dead cells) were 7.0-fold and 4.6-fold higher, respectively, in cultures treated with substances $\mathbf{5}$ and $\mathbf{4}$ in relation to control groups. In addition, it was demonstrated that substances $\mathbf{4}$ and $\mathbf{5}$ altered the MCF-7 cell cycle progression. There 
Table 2. Half maximal inhibitory concentration $\left(\mathrm{IC}_{50}\right)$ values determined by resazurin assay after $48 \mathrm{~h}$ treatment on normal peripheral blood mononuclear cells tumor cells (PBMC) and cell lines derived from human breast cancer (MCF-7, Hs578T, and MDA-MB-231) and non-small cell lung cancer (A549)

\begin{tabular}{|c|c|c|c|c|c|}
\hline \multirow{2}{*}{ Compound } & \multicolumn{5}{|c|}{$\mathrm{IC}_{50} \pm \mathrm{SD} / \mu \mathrm{M}$} \\
\hline & MCF-7 & Hs578T & MDA-MB-231 & A549 & PBMC \\
\hline 4 & $95.64 \pm 1.45$ & $152.00 \pm 3.21$ & $>150$ & ND & $>1000$ \\
\hline 5 & $58.00 \pm 0.49$ & $>150$ & $116.50 \pm 2.67$ & $76.66 \pm 2.45$ & $>400$ \\
\hline Ketoprofen $^{\mathrm{a}}$ & $>150$ & ND & ND & $>150$ & $>500$ \\
\hline Cisplatin $^{\mathrm{b}}$ & $16.44 \pm 2.48$ & $18.73 \pm 1.54$ & $35.17 \pm 2.45$ & $21.75 \pm 1.17$ & NP \\
\hline
\end{tabular}

${ }^{a}$ Ketoprofen was used as a typical anti-inflammatory drug. ${ }^{\mathrm{b}}$ Cisplatin was used as a typical antineoplastic drug. SD: standard deviation; ND: not determined because cell viability was not enough reduced to determine $\mathrm{IC}_{50}$ values; NP: not performed.

was an increase of the G1 population with a concomitant reduction in the $S$ population in treated samples compared to control groups (Figure $5 \mathrm{~b}$ and Table 3). These findings indicate that substances $\mathbf{4}$ and $\mathbf{5}$ inhibited the cell cycle at G1/S transition. Further reduction of cyclin E expression was evidenced by immunoblot in samples treated with substances $\mathbf{4}$ and $\mathbf{5}$ (Figure 5c). Cell cycle progression is highly regulated by sequential activation and deactivation of specific cyclin-CDK (cyclin-dependent kinase) complexes, in which the cyclins are regulatory subunits. G1 progression and $\mathrm{G} 1 / \mathrm{S}$ transition are regulated by cyclin D-CDK $4 / 6$ and cyclin E-CDK2 complexes, respectively. ${ }^{50} \mathrm{G} 1 / \mathrm{S}$ transition is a critical step for cell proliferation. ${ }^{51}$ Deregulated expression of cell cycle regulators is frequently observed in cancer cells, and overexpression of cyclins D and $\mathrm{E}$ have been reported in different subtypes of breast cancer. ${ }^{52-55}$ Moreover, overexpression of cyclin $\mathrm{E}$ has been correlated with resistance to hormonal therapy and poor patient outcomes. ${ }^{56,57}$ Cell cycle arrest at G1/S transition was reported in MCF-7 cells when exemestane, an aromatase inhibitor, was used in combination with NSAID..$^{58}$ Thus, substances $\mathbf{4}$ and $\mathbf{5}$ may be valuable prototypes for breast cancer therapy due to their ability to inhibit cyclin E expression and, in turn, provoke cell cycle arrest at G1/S transition.

Taken together, the data show that compounds $\mathbf{4}$ and 5 have anti-inflammatory and antiproliferative activity on
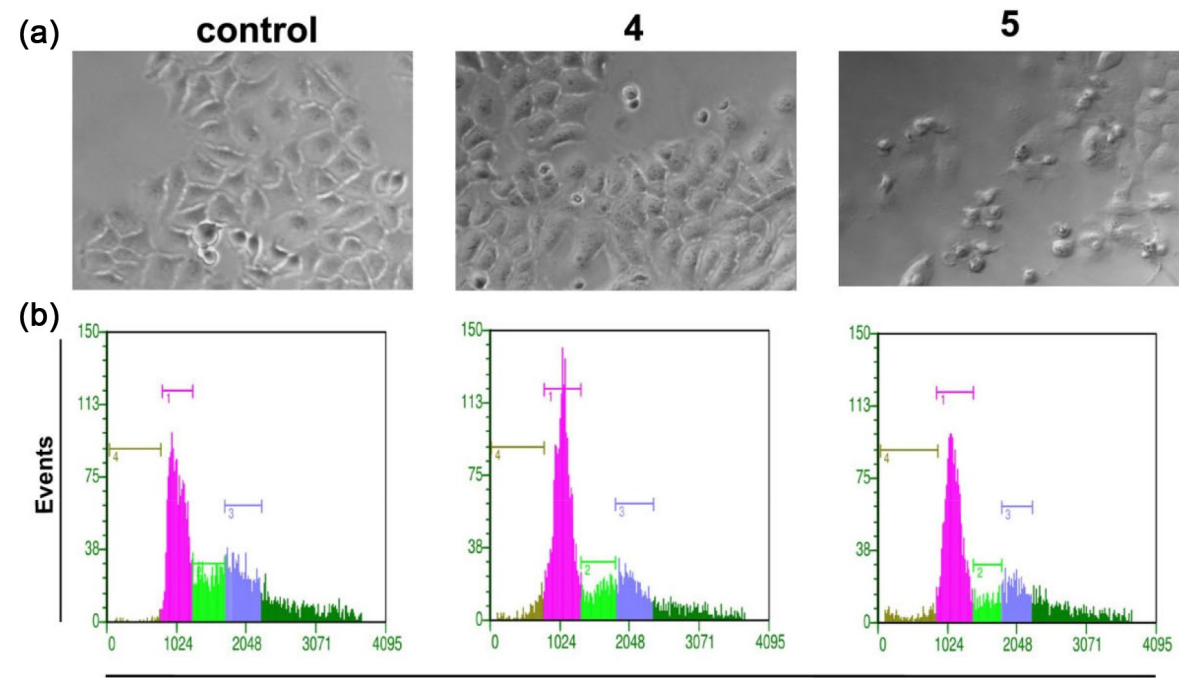

DNA content

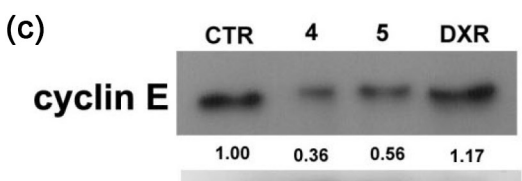

$\alpha$-tubulin

Figure 5. (a) Images obtained by phase-contrast microscopy evidencing the morphological features of MCF-7 cells $(60 \times$ magnification $)$ after treatment with compounds $\mathbf{4}$ and $\mathbf{5}$ for $48 \mathrm{~h}$ in concentrations equivalent to $\mathrm{IC}_{50}$. (b) Histograms obtained by flow cytometry show different cell populations according to their DNA content. Sub-G1 (brown), G0/G1 (pink), S (green), and G/M (blue). (c) Immunoblot evidencing immunoreactive bands for cyclin E. $\alpha$-Tubulin was used as a loading control. DXR: doxorubicin at $3 \mu \mathrm{M}$. 
Table 3. Cell cycle analysis after $48 \mathrm{~h}$ treatment

\begin{tabular}{lcccc}
\hline & Sub-G1 & G0/G1 & S & G2/M \\
\hline Control vehicle & $1.05 \pm 0.17$ & $52.06 \pm 1.09$ & $20.73 \pm 0.52$ & $20.16 \pm 0.76$ \\
$\mathbf{4}(100 \mu \mathrm{M})$ & $4.86 \pm 0.29^{\mathrm{a}}$ & $62.17 \pm 0.33^{\mathrm{a}}$ & $14.03 \pm 0.18^{\mathrm{b}}$ & $18.93 \pm 0.81$ \\
$\mathbf{5}(60 \mu \mathrm{M})$ & $7.43 \pm 0.25^{\mathrm{a}}$ & $62.96 \pm 0.71^{\mathrm{a}}$ & $11.24 \pm 0.30^{\mathrm{a}}$ & $18.37 \pm 0.87$ \\
\hline
\end{tabular}

${ }^{\mathrm{a}} p<0.001 ;{ }^{\mathrm{b}} p<0.01$ according to the analysis of variance (ANOVA) followed by Tukey's post-hoc test from three independent experiments.

MCF-7 cells. These findings support further in vivo studies to evaluate the efficacy of these substances on breast cancer.

\section{Conclusions}

Glucosyl analogs of ketoprofen were synthesized and evaluated for the first time as new anti-inflammatory and antiproliferative agents. Molecular modeling studies showed that glucoside $\mathbf{4}$ has a higher affinity for COX-1 and COX-2 than ketoprofen. In in vitro studies, the glucoside 4 selectively inhibited COX-2 while its aglycone, the benzophenone $\mathbf{5}$, selectively inhibited the COX-1 isoform. In addition, we demonstrated that these two compounds have in vivo anti-inflammatory effect and inhibit cell cycle arrest at G1/S transition in MCF-7 cells. Anti-inflammatory activity was attributed to their ability to inhibit selectively COX enzymes, but other pathways which were not evaluated also can contribute. While antitumor potential, at least in part, was due to their ability to modulate cyclin E expression. Thus, this study provides strong evidence that these substances have both antiproliferative and anti-inflammatory activities, deserving further studies to evaluate their applicability as an antitumor agent for breast cancer therapy.

\section{Supplementary Information}

Supplementary file (containing the NMR, MS, and IR spectra of the synthesized compounds and table of molecular docking results) is available free of charge at https://jbcs.sbq.org.br as a PDF file.

\section{Acknowledgments}

The authors acknowledge the funding agencies for fellowships and financial support for this research project: FAPEMIG (APQ-01641-12, APQ-01209-13; APQ-03245-15), CNPq (427497/2018-3), Coordenação de Aperfeiçoamento de Pessoal de Nível Superior-Brasil (CAPES) (Finance Code 001), Rede Mineira de Química (RQ-MG) supported by FAPEMIG (CEX-RED-00010-14), and National Council for Scientific and Technological Development-CNPq, for providing fellowship for MPV.

\section{Author Contributions}

LRSF, DFD, DTC, IMN, JPJ, MHS, MGS, TBS were responsible for investigation, methodology (study design, synthesis, and characterization of compounds); MECM, JPJ, MGS, DACP for investigation, methodology (ear edema and COX inhibition); BTVB, MPV for investigation, methodology (modeling model); ROH, LFLC, MI for investigation, methodology (cytotoxic assays); LRSF, JPJ, TBS, DACP, DFD, MI, MPV for writing original draft; LRSF, DACP, DFD, TBS, TBS, MHS, MI for conceptualization; DACP, DTC, TBS, DFD, MGS, MI for writing review and editing, investigation, supervision, project administration.

\section{References}

1. Mantovani, A.; Allavena, P.; Sica, A.; Balkwill, F.; Nature 2008, 454,436

2. Crusz, S. M.; Balkwill, F. R.; Nat. Rev. Clin. Oncol. 2015, 12, 584.

3. Matkowskyj, K. A.; Chen, Z. E.; Rao, M. S.; Yang, G.; Arch. Pathol. Lab. Med. 2013, 137, 338.

4. Yang, Z.; Kang, J.; Kim, H. S. H.; Park, A.; Kim, H. S. H.; Bull. Korean Chem. Soc. 2009, 30, 1463.

5. Nan, H.; Morikawa, T.; Suuriniemi, M.; Imamura, Y.; Werner, L.; Kuchiba, A.; Yamauchi, M.; Hunter, D. J.; Kraft, P.; Giovannucci, E. L.; Fuchs, C. S.; Ogino, S.; Freedman, M. L.; Chan, A. T.; JNCI, J. Natl. Cancer Inst. 2013, 105, 1852.

6. Chung, C. P.; Avalos, I.; Raggi, P.; Stein, C. M.; Clin. Rheumatol. 2007, 26, 1228.

7. Coussens, L. M.; Werb, Z.; Neĭman, I. M.; Nature 2002, 420, 860.

8. Wyss-Coray, T.; Nat. Med. 2006, 12, 1005.

9. Dannhardt, G.; Eur. J. Med. Chem. 2002, 37, 147.

10. Brune, K.; Patrignani, P.; J. Pain Res. 2015, 8, 105.

11. Rajić, Z.; Hadjipavlou-Litina, D.; Pontiki, E.; Balzarini, J.; Zorc, B.; Med. Chem. Res. 2011, 20, 210.

12. Kalgutkar, A. S.; Crews, B. C.; Rowlinson, S. W.; Marnett, A. B.; Kozak, K. R.; Remmel, R. P.; Marnett, L. J.; Proc. Natl. Acad. Sci. U. S. A. 2000, 97, 925.

13. Ali, S. M. M.; Jesmin, M.; Azad, M. A. K.; Islam, M. K.; Zahan, R.; Asian Pac. J. Trop. Biomed. 2012, 2, S1036.

14. Khanum, S. A.; Shashikanth, S.; Deepak, A. V.; Bioorg. Chem. 2004, 32, 211. 
15. Santa-Cecília, F. V.; Freitas, L. A. S.; Vilela, F. C.; Veloso, C. C.; da Rocha, C. Q.; Moreira, M. E. C.; Dias, D. F.; GiustiPaiva, A.; dos Santos, M. H.; Eur. J. Pharmacol. 2011, 670, 280.

16. Zabiulla; Gulnaz, A. R.; Mohammed, Y. H. E.; Khanum, S. A.; Bioorg. Chem. 2019, 92, 103220.

17. Zhang, D.; Liu, R.; Sun, L.; Huang, C.; Wang, C.; Zhang, D. M.; Zhang, T. T.; Du, G. H.; Molecules 2011, 16, 3875.

18. Khalifa, N. M.; Ramla, M. M.; Amr, A. E. E.; Abdulla, M. M.; Phosphorus, Sulfur Silicon Relat. Elem. 2008, 183, 3046.

19. Ottosen, E. R.; Sørensen, M. D.; Björkling, F.; Skak-Nielsen, T.; Fjording, M. S.; Aaes, H.; Binderup, L.; J. Med. Chem. 2003 , 46, 5651

20. Palomer, A.; Pascual, J.; Cabré, M.; Borràs, L.; González, G.; Aparici, M.; Carabaza, A.; Cabré, F.; García, M. L.; Mauleón, D.; Bioorg. Med. Chem. Lett. 2002, 12, 533.

21. Palomer, A.; Pérez, J. J.; Navea, S.; Llorens, O.; Pascual, J.; García, L.; Mauleón, D.; J. Med. Chem. 2000, 43, 2280.

22. Badal, S. A. M.; Asuncion Valenzuela, M. M.; Zylstra, D.; Huang, G.; Vendantam, P.; Francis, S.; Quitugua, A.; Amis, L. H.; Davis, W.; Tzeng, T. J.; Jacobs, H.; Gangemi, D. J.; Raner, G.; Rowland, L.; Wooten, J.; Campbell, P.; Brantley, E.; Delgoda, R.; J. Appl. Toxicol. 2017, 37, 873.

23. la Ferla, B.; Airoldi, C.; Zona, C.; Orsato, A.; Cardona, F.; Merlo, S.; Sironi, E.; D’Orazio, G.; Nicotra, F.; Nat. Prod. Rep. 2011, 28, 630 .

24. Kleine, H. P.; Weinberg, D. V.; Kaufman, R. J.; Sidhu, R. S.; Carbohydr. Res. 1985, 142, 333.

25. de Souza, T. B.; Raimundo, P. O. B.; Andrade, S. F.; Hipolito, T. M. M.; Silva, N. C.; Dias, A. L. T.; Ikegaki, M.; Rocha, R. P.; Coelho, L. F. L.; Veloso, M. P.; Carvalho, D. T.; Dias, D. F.; Carbohydr. Res. 2015, 410, 1.

26. Jacobsson, M.; Malmberg, J.; Ellervik, U.; Carbohydr. Res. 2006, 341, 1266.

27. Mitchell, S. A.; Pratt, M. R.; Hruby, V. J.; Polt, R.; J. Org. Chem. 2001, 66, 2327.

28. Sasse, A.; Ligneau, X.; Sadek, B.; Elz, S.; Pertz, H. H.; Ganellin, C. R.; Arrang, J.; Schwartz, J.; Schunack, W.; Stark, H.; Arch. Pharm. (Weinheim) 2001, 334, 45.

29. de Souza, T. B.; Orlandi, M.; Coelho, L. F. L.; Malaquias, L. C. C.; Dias, A. L. T.; de Carvalho, R. R.; Silva, N. C.; Carvalho, D. T.; Med. Chem. Res. 2014, 23, 496.

30. Chagas-Paula, D. A.; de Oliveira, R. B.; da Silva, V. C.; GobboNeto, L.; Gasparoto, T. H.; Campanelli, A. P.; Faccioli, L. H.; da Costa, F. B.; J. Ethnopharmacol. 2011, 136, 355.

31. Tubaro, A.; Dri, P.; Delbello, G.; Zilli, C.; Della Loggia, R.; Agents Actions 1985, 17, 347.

32. Domingos, O. D. S.; Alcântara, B. G. V.; Santos, M. F. C.; Maiolini, T. C. S.; Dias, D. F.; Baldim, J. L.; Lago, J. H. G.; Soares, M. G.; Chagas-Paula, D. A.; Molecules 2019, 24, 4375 .
33. Santos, M. F. C.; Alcântara, B. G. V.; Feliciano, C. R.; Silva, A. F.; Maiolini, T. C. S.; Neto, A. K.; Murgu, M.; de Paula, D. A. C.; Soares, M. G.; Phytochem. Lett. 2019, 30, 31.

34. Schrödinger suite, Maestro, version 9.2; Schrödinger, LLC, New York, USA, 2011.

35. Schrödinger suite, LigPrep, version 2.5; Schrödinger, LLC, New York, USA, 2011.

36. Schrödinger suite, Prime, version 3.0; Schrödinger, LLC, New York, USA, 2011.

37. Schrödinger suite, MacroModel, version 9.9; Schrödinger, LLC, New York, USA, 2011.

38. Schrödinger suite, Induced Fit Docking Protocol, version 9.9; Schrödinger, LLC, New York, USA, 2011.

39. Chagas-Paula, D.; Oliveira, T.; Faleiro, D.; Oliveira, R.; da Costa, F.; Planta Med. 2015, 81, 1296.

40. Sales, L.; de Sousa, G. R.; Ferreira-Silva, G. Á.; Castro-Gamero, A. M.; Ionta, M.; de Oliveira, J. C.; Anticancer Drugs 2017, 28, 298.

41. Abrão, P. H. O.; Pizi, R. B.; de Souza, T. B.; Silva, N. C.; Fregnan, A. M.; Silva, F. N.; Coelho, L. F. L.; Malaquias, L. C. C.; Dias, A. L. T.; Dias, D. F.; Veloso, M. P.; Carvalho, D. T.; Chem. Biol. Drug Des. 2015, 86, 459.

42. Tang, Y.; Liu, X.; Yu, B.; J. Asian Nat. Prod. Res. 2003, 5, 257.

43. Ferreira-Silva, G. A.; Ortega, M. M.; Banionis, M. A.; Garavelli, G. Y.; Martins, F. T.; Dias, J. S. M.; Viegas Jr., C.; de Oliveira, J. C.; do Nascimento, F. B.; Doriguetto, A. C.; Barbosa, M. I. F.; Ionta, M.; Toxicol. In Vitro 2017, 44, 382.

44. Stallforth, P.; Lepenies, B.; Adibekian, A.; Seeberger, P. H.; J. Med. Chem. 2009, 52, 5561.

45. Crich, D.; Acc. Chem. Res. 2010, 43, 1144.

46. Chowdhury, M. A.; Dong, Y.; Chen, Q.-H.; Abdellatif, K. R. A.; Knaus, E. E.; Bioorg. Med. Chem. 2008, 16, 1948.

47. Sidhu, R. S.; Lee, J. Y.; Yuan, C.; Smith, W. L.; Biochemistry 2010, 49, 7069.

48. Wahba, H. A.; El-Hadaad, H. A.; Cancer Biol. Med. 2015, 12, 106.

49. Al-Mahmood, S.; Sapiezynski, J.; Garbuzenko, O. B.; Minko, T.; Drug Delivery Transl. Res. 2018, 8, 1483.

50. Lapenna, S.; Giordano, A.; Nat. Rev. Drug Discovery 2009, 8, 547.

51. Johnson, J.; Thijssen, B.; McDermott, U.; Garnett, M.; Wessels, L. F. A.; Bernards, R.; Oncogene 2016, 35, 4829.

52. Luhtala, S.; Staff, S.; Tanner, M.; Isola, J.; Tumor Biol. 2016, 37, 9813.

53. Alexander, A.; Karakas, C.; Chen, X.; Carey, J. P. W.; Yi, M.; Bondy, M.; Thompson, P.; Cheung, K. L.; Ellis, I. O.; Gong, Y.; Krishnamurthy, S.; Alvarez, R. H.; Ueno, N. T.; Hunt, K. K.; Keyomarsi, K.; Oncotarget 2017, 8, 14897.

54. Ortiz, A. B.; Garcia, D.; Vicente, Y.; Palka, M.; Bellas, C.; Martin, P.; PLoS One 2017, 12, e0188068. 
55. Llobet, S. G.; van der Vegt, B.; Jongeneel, E.; Bense, R. D.; Zwager, M. C.; Schröder, C. P.; Everts, M.; Fehrmann, R. S. N.; de Bock, G. H.; van Vugt, M. A. T. M.; npj Breast Cancer 2020, 6,40 .

56. Caldon, C. E.; Sergio, C. M.; Kang, J.; Muthukaruppan, A.; Boersma, M. N.; Stone, A.; Barraclough, J.; Lee, C. S.; Black, M. A.; Miller, L. D.; Gee, J. M.; Nicholson, R. I.; Sutherland, R. L.; Print, C. G.; Musgrove, E. A.; Mol. Cancer Ther. 2012, 11,1488 .
57. Caldon, C. E.; Sergio, C. M.; Schütte, J.; Boersma, M. N.; Sutherland, R. L.; Carroll, J. S.; Musgrove, E. A.; Mol. Cell. Biol. 2009, 29, 4623.

58. Hu, L.; Du, Y.; Zhang, Y.; Pan, Y.; Asian Pac. J. Cancer Prev. 2012, 13, 5903.

Submitted: August 28, 2021 Published online: November 17, 2021 